\title{
GIS-Based Digital Terrain Analysis of Assam-Meghalaya Foothills in Kamrup District, Assam
}

\author{
C. Borpujari† and A. K. Bora \\ Department of Geography, Guwahati University, Guwahati-781014, Assam, India \\ $\nmid$ Corresponding author: C. Borpujari; chinmoyeecb@gmail.com
}

Nat. Env. \& Poll. Tech.

Website: www.neptjournal.com

Received: 24-01-2021

Revised: 22-03-2021

Accepted: 14-04-2021

Key Words:

Terrain

Geomorphology

Foothills

GIS

Digital terrain analysis

\section{ABSTRACT}

Terrain characteristics and their evaluation usually come under geomorphological study and more particularly the applied geomorphological study (Prasad \& Sarkar 2011). Foothills are a geographically defined zone having a gradual increase in elevation at the base of a mountain or hill range. Detailed assessment of the present terrain parameters of the study area using GIS is significant as it shows the influence on the landscape of the area. It is a prerequisite in effective management of the impact of transition upon the landscape and its natural resources for sustainable management. In the study, an attempt has been made to delineate the foothill belt of the Assam-Meghalaya border in Kamrup District, Assam using Geographical Information system (GIS), and remote sensing techniques. Datasets available from USGS Earth Explorer, i.e. Shuttle Radar Topographic Mission (SRTM) and Digital Elevation Model (DEM) are used for analyzing the elevation, contour, slope, and terrain characteristics. The present study aims at getting an information archive of the geomorphological and terrain characteristics of the Assam-Meghalaya foothills in Kamrup District, Assam, and its spatiotemporal variations.

\section{INTRODUCTION}

The general configuration of the landscape, its geology, climate, and other natural features define the terrain. Terrain means landscape or the 'Lay of land'. Terrain classification is a process of classifying the earth's surface based on the similarities in terrain properties, geomorphology, geological and morphometric properties, soil types, etc. into different units (Saha et. al. 2019). Evaluation of terrain characteristics and analysis of geo-environmental changes are considered important themes in geographical studies. With the introduction of digital spatial technology, the use of quantitative measurements to evaluate, monitor, and interpret landform changes is becoming more prevalent (Summerfield 1997, Wood 1996). The analysis of the terrain characteristics included delineation of the various terrain features, such as elevation, elevation profile, geology, hydrogeology, geomorphological units, soil, and contours. The landforms observed in the present day are the result of the long-term interactions between the elements of the geosphere, atmosphere, and hydrosphere (Manjare et.al. 2020). Surface subsurface materials, as well as the area's landforms, are depicted in the representation of geomorphological features. Sketches and maps of landscapes and landforms (Dykes 2008) have been used in Digital Terrain Analysis to analyze and visualize earth surface features ever since early geomorphological research. Mapping of terrain and geomorphological characteristics can act as a preliminary tool for the baseline study of landscape ecology, forestry, soil science, land management, geomorphological and geological assessment (Cooke \& Doornkamp 1990, Dramis et al. 2011, Paron \& Claessens 2011). Digital Elevation Model is simply called the digital description of the earth's surface or terrain condition of earth as a whole or part of it (Bolstad \& Stowe 1994). These are widely used in earth sciences for terrain and topographic study. The application of GIS is an essential tool for digital terrain analysis. The analysis of topographic attributes of a particular area depends on elevation data acquired from satellite imagery, contour lines generated from topographic maps, and ground surveys (Wilson \& Gallant 2000). Foothills are the transitional eco-sensitive zone with low relief hills between the plains and topographically high mountains. The study of the terrain characteristics of these foothills is thus important in sustainable resource utilization and planned development with an eco-centric viewpoint in the study area.

\section{Study Area}

The study area is confined to the Assam-Meghalaya foothill belt bordering the Kamrup district of Assam. Kamrup district is surrounded by Kamrup Metropolitan district in the east, Goalpara district in the west, Darrang district in the north and Meghalaya state in the south (Fig. 1). The foothill zone occupies a total geographical area of $778.27 \mathrm{~km}^{2}$. The northern 


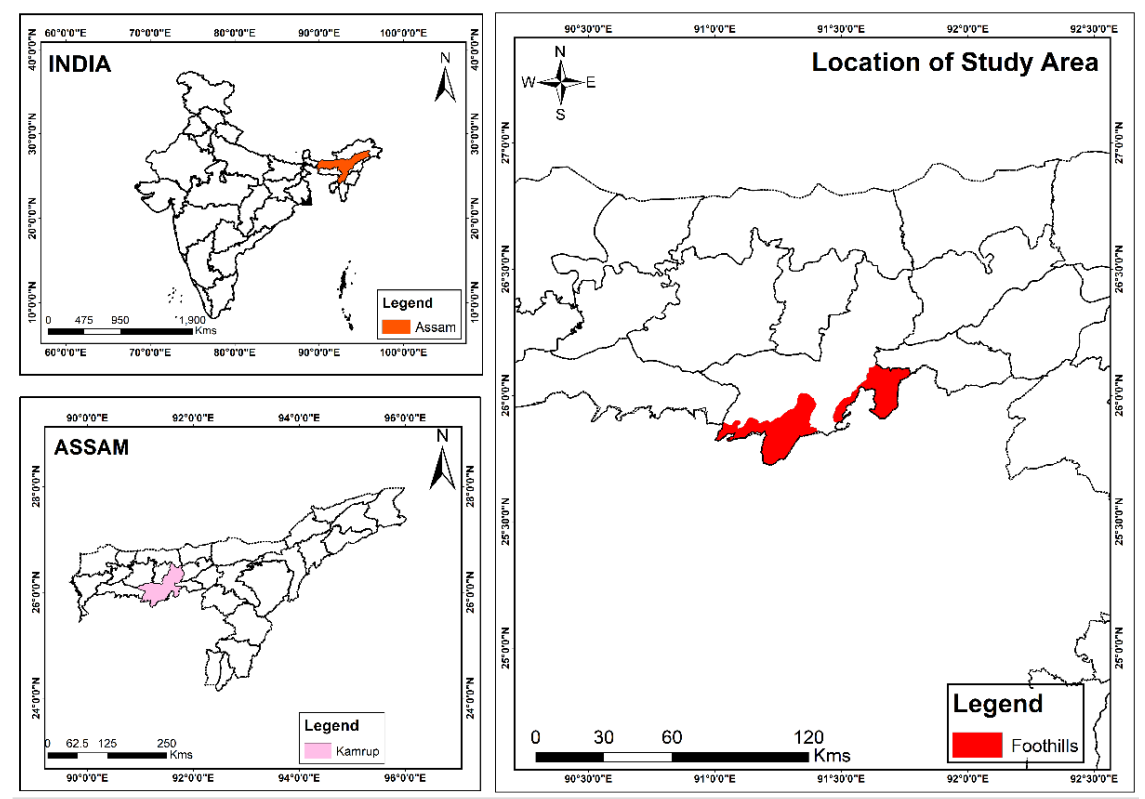

Fig. 1: Location of the study area.

foothills of the Meghalaya plateau along the Assam-Meghalaya border are formed of Achaean rocks, which comprise the metamorphic rock types of gneisses and schist. This foothill belt of the Assam-Meghalaya border is the northward projections of Garo hills and the Khasi-Jaintia hills. These hills gradually lose their elevation northward to merge with the Brahmaputra plains through gentle gradients punctuated occasionally by isolated hills and hillocks. The foothill zone along Kamrup district under study stretches for a distance of about $78.6 \mathrm{~km}$ from west to east with an elevation ranging from 42-1124 meters. Geographically, the Assam-Meghalaya foothill belt bordering the Kamrup district lies between geo-coordinates $91^{\circ} 0^{\prime} 3.338^{\prime \prime} \mathrm{E}$ and $91^{\circ} 46^{\prime} 22.82^{\prime \prime} \mathrm{E}$ longitude and $26^{\circ} 0^{\prime} 4.432^{\prime \prime} \mathrm{N}$ and $26^{\circ} 13^{\prime} 46.372^{\prime \prime} \mathrm{N}$ latitude.

\section{Objectives of the study}

The objectives of the proposed research work are:

1. To analyze the terrain characteristics of the foothill belt of the Assam-Meghalaya region along the Kamrup district of Assam.

2. To analyze the associated geomorphology and relief pattern of the foothill belt.

\section{MATERIALS AND METHODS}

The methodology adopted for the study uses both primary and secondary data of the area. The data from various government sources, reports, and publications, is collected and thoroughly analyzed, and personal observations are made throughout the study area. Using GIS and satellite data, the terrain is classified and mapped. The data prepared is marked and executed on the map. The topographical map numbering, viz. $78 \mathrm{O} / 1,78 \mathrm{O} / 5,78 \mathrm{O} / 9$, and $78 \mathrm{~N} / 12$ on a scale of 1:50,000 prepared by the Survey of India are used for delineation of various features in the foothill zone. Spatial information of terrain and relief characteristics are evaluated using geological data and maps collected from the Geological Survey of India.

\section{RESULTS AND DISCUSSION}

\section{Elevation}

The altitude of the study area varies between 42 and 1124 meters. This foothill belt is embodied with rugged topography towards the southernmost range, which gradually loses its elevation towards the north and north-western part. The highest elevation is 1124 meters found in the southern part. Altitude is continuously falling from south to north and east. The eastern part of the foothills where river valleys are present is almost flat. The highest elevation is observed in the southernmost part near Rani hills, Lumpi, Umtap, and Lower Lumpi, and, lowest elevated areas have been found in the surrounding valley region of the Kulsi river, Namtarabari area, Hahim, and valley of Rani (Fig. 2).

Relief profiles of the foothill belt in Kamrup show the distribution of the relief and give the elevation profile of the 


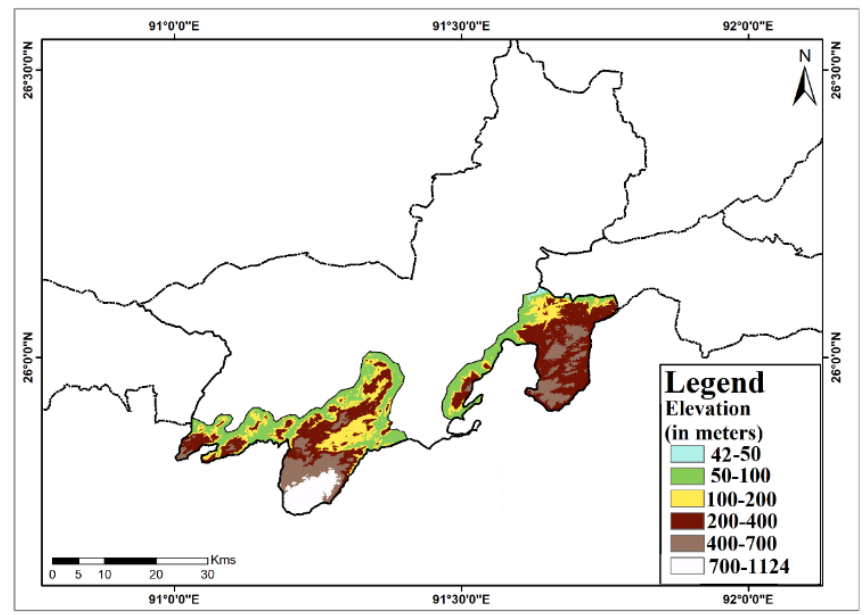

Fig. 2: Elevation of the foothill belt.

hills. The relief profiles along $\mathrm{AB}$ and $\mathrm{CD}$ cross-sections show the highest elevation in the southernmost part of the Boko revenue circle along the $\mathrm{AB}$ cross-section, while the $\mathrm{CD}$ cross-section along the Rani-Garbhanga region has relatively moderate relief, i.e. 42 to 650 meters above MSL (Fig. 3).

\section{Geology}

Geologically, the study area mainly consists of the Pre-Cambrian gneissic complex $\left(493 \mathrm{~km}^{2}\right)$, and New Alluvium or Recent formation $\left(290 \mathrm{~km}^{2}\right)$. The foothill region of the Assam-Meghalaya border situated in Kamrup district is geologically made up of a Pre-Cambrian gneissic complex composed of granite gneiss, biotic schist, gneiss, and quartz. These hills are the parts of the West Khasi hills, which are principally composed of gneisses and schists of Gondwana land with intrusive granite, whereas parts of the study area exhibit the characteristics of the Assam valley. Geologically, the foothill zone may be divided into two broad groups, viz

(i) Archaean, and (ii) New Alluvium or Recent Formation (Fig. 4).

(i) Archaean: The Archaean group comprises a metamorphic complex of gneisses and schist complex with young acidic/basic intrusive. It covers $493 \mathrm{~km}^{2}$ of the area in the southernmost part of the foothill belt.

(ii) New Alluvium: New Alluvium or Recent formation is represented by alluvial deposits of recent age by the Brahmaputra river system and its tributaries. This is the most recent geological classification in the study area.

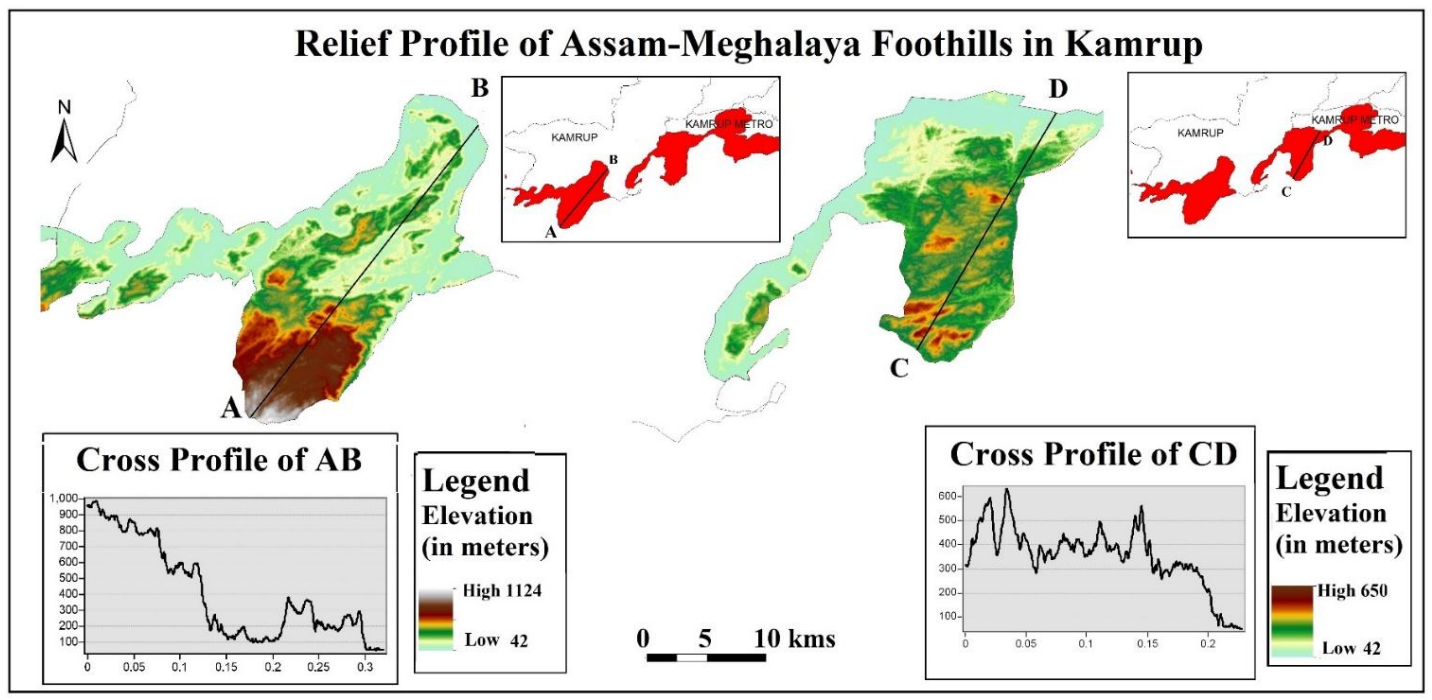

Fig. 3: Cross Profile of $\mathrm{AB}$ and $\mathrm{CD}$ cross-sections of the foothill belt 
Medium to coarse grain sand, gravel, pebbles, cobbles with silt, and clay is the prime characteristics of New Alluvium or Recent formation covering an area of 290 $\mathrm{km}^{2}$. The geological formations of the Assam-Meghalaya border situated in the Kamrup district are shown in Fig. 4.

\section{Hydrogeology}

Hydrogeologically, the study area is divided into two units, namely consolidated formations and unconsolidated formations (Fig. 5). The newer alluvium zones of the Assam-Meghalaya foothill belt are characterized as unconsolidated formations. This newer alluvium belt of the quaternary and upper Tertiary age group is high in groundwater potential ranging from 150 to $200 \mathrm{~m}^{3}$. hr $\mathrm{hr}^{-1}$. This belt spreads throughout the northernmost foothills of Kamrup covering a total geographical area of $298.99 \mathrm{~km}^{2}$. The consolidated zone of the Archaean age group is the entire structured hill zone of the foothill belt. This belt is found in the southernmost part along the hills of Talimara, Rani, and Garbhanga in Kamrup covering a total area of $484.71 \mathrm{~km}^{2}$. Groundwater potential is low at $5 \mathrm{~m}^{-3} \cdot \mathrm{hr}^{-1}$ (CGWB 2012).

\section{Slope Analysis}

The slope is an angular inclination of the region between crests and the base of the valley. Slope analysis of the foothill belt is done by quantifying the maximum rate of change in values of elevation from each cell to its neighbours. It is observed that along the foothill belt, steep slopes are found along the types of ridges and the flat areas aligned with the river valleys. The slope information is useful in understanding the topography, geomorphology, soil types and their erodibility, and surface drainage (Manjare 2013). The slope map was prepared for the study area using SRTM (DEM)

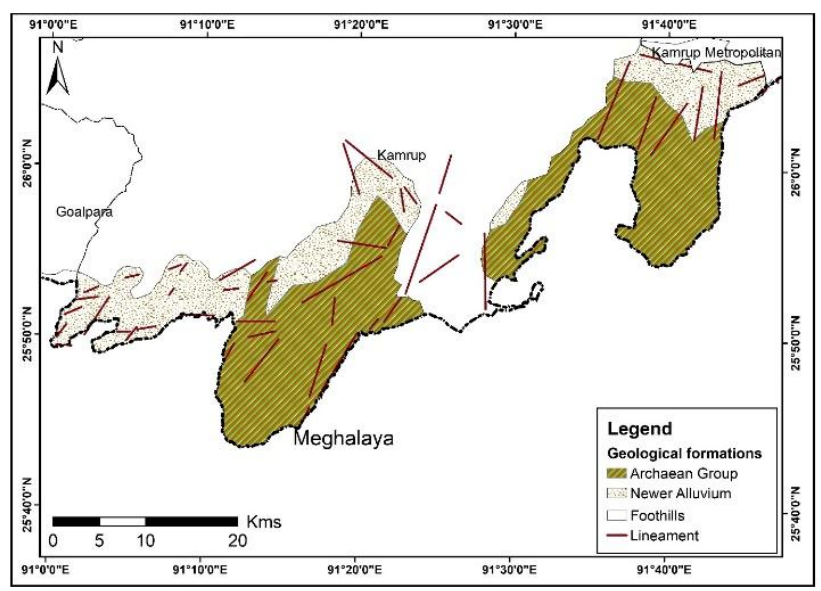

Fig. 4: Geology of the foothill belt. data (Fig. 6). The slope in the study area was calculated in degrees and categorized into five slope classes, namely zero to three degrees, which covered an area of $98.00 \mathrm{~km}^{2}$ of the total area of the foothills $(12.60 \%)$. These areas were levelled plains. Slope ranging between three to eight degrees which were gentle slope covered an area of $145.36 \mathrm{~km}^{2}(18.68 \%)$, areas of moderate slope class with slope range of 8 to 18 degrees covered $283.16 \mathrm{~km}^{2}$ (36.40\%), areas of steep slope class with slope range of 18 to 29 degrees covered 192.09 $\mathrm{km}^{2}(24.65 \%)$, and high slope values of 29 to 65.6 degrees were distributed over an area of $59.66 \mathrm{~km}^{2}(7.67 \%)$ of the total geographical area of the foothill belt (Table 1).

\section{Geomorphic Units and their Characteristics}

The objective of delineating relief zones for terrain classification is taken up to indicate broad and generalized landform types. In the study area, distinct geomorphic units were delineated based on the analysis of SRTM DEM, and SOI toposheets. The geomorphic units identified and delineated in the study area have been categorized under (1) Denudational origin, 2) Fluvial origin, 3) Structural origin and 4) Waterbodies (Fig. 7).

\section{(1) Denudational origin}

The denudational structure observed in the foothill zone includes low dissected hill, moderately dissected plateaus, pediment-pediplain complex, residual hill, valley fills, etc. These denudation hills lie between the rugged terrain hills and the valleys distributed unevenly in the foothill belt. The extended low-lying hills of Kamrup covering a total area of $47.8 \mathrm{~km}^{2}$ are available at the junction of the plains in the northern part of the foothills.

\section{(2) Fluvial origin}

The landforms created due to fluvial agents are of fluvial origin. The fluvial landforms found in the foothill zone are

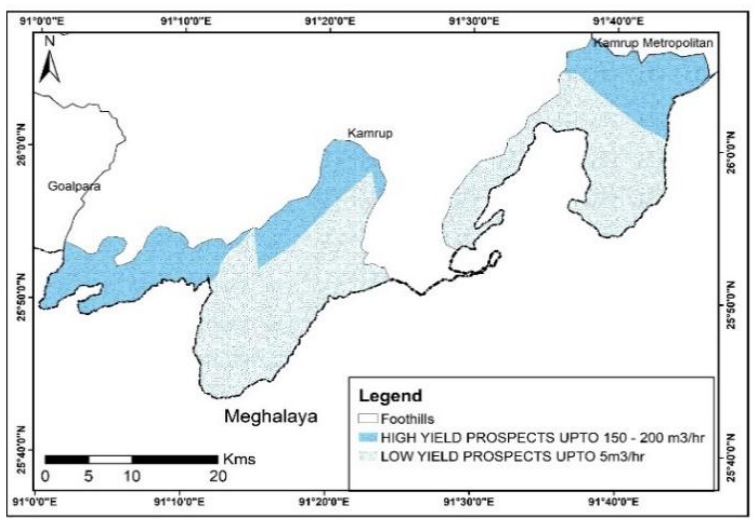

Fig. 5: Hydrogeology of the foothill belt. 
flood plains, valleys, alluvial plains, abandoned channels, paleochannels, natural levees, floodplains, etc. These surround the river valleys of Kulsi, Bhatanadi, Kalibog Nadi valley in Kamrup and covers a total area of $55.20 \mathrm{~km}^{2}$ accounting for $7.10 \%$ of the foothill belt of the Kamrup district.

\section{(3) Structural origin}

The Archaean gneisses complex of the foothill zone is entirely of structural origin. This geomorphic unit has a dramatic effect on the genesis of landforms in the study area and influences the structural setup of the area. These landforms are found in the high elevated extended hills of the Meghalaya plateau, mostly in the dense forested hills of the southernmost part of the foothills. It covers a total area of $674.07 \mathrm{~km}^{2}$, i.e. $86.61 \%$ of the foothill belt in the Kamrup district.

\section{(4) Waterbodies}

In the study area, water bodies include rivers, tributaries, offshoot streams, ponds, wetlands, or more rarely, puddles. Chandubi lake, Deepor Beel are few wetlands in the foothill belt covering a total area of $1.20 \mathrm{~km}^{2}$, i.e. $0.15 \%$ of the total area of the foothills under the district.

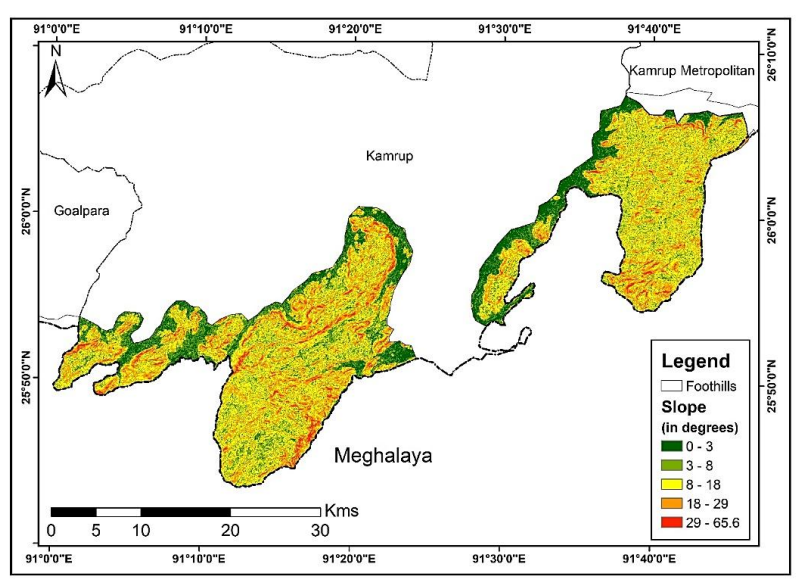

Fig. 6: Slope analysis of the of the foothill belt.

Table 1: Area under different slope classes of the study.

\begin{tabular}{|lll|}
\hline $\begin{array}{l}\text { Slope Class } \\
\text { (in degrees) }\end{array}$ & $\begin{array}{l}\text { Area under different slope } \\
\text { classes (in } \mathrm{km}^{2} \text { ) }\end{array}$ & Area (in \%) \\
\hline 0 to 3 & 98.00 & 12.6 \\
3 to 8 & 145.36 & 18.68 \\
8 to 18 & 283.16 & 36.4 \\
18 to 29 & 192.09 & 24.65 \\
29 to 65.6 & 59.66 & 7.67 \\
Total Area & 778.27 & \\
\hline
\end{tabular}

\section{Relief units}

The objective of delineating relief zones for terrain classification is taken up to indicate broad and generalized landform types. The relief division of the foothills broadly includes three types- valley fill shallows, residual hills, and structural hills (Fig. 8).

\section{a) Valley fill}

Valley fills are identified in between the hill ranges and are filled with sand, silt, alluvial deposits, gravel, etc. These valley fills are distributed in large areas over the foothill belt surrounding the tributaries of the Brahmaputra. These are located in the low elevated region of river valleys such as Kulsi, Bhatanadi, Mora Kulsi valley of the foothill zone and covering a total area of $291.37 \mathrm{~km}^{2}$, i.e. $37.44 \%$ of the foothill belt of the Kamrup District.

\section{b) Residual hill}

Residual hills are complex formations and are in conjunction with both alluvial plains and hills surrounding the foothill zone. These range from 120 to $800 \mathrm{~m}$ above mean sea level in the foothill zone. These hills are found surrounding the structural hills of greater elevation. Kahikuchi, surrounding hillocks around Deepor Beel, Pamohi, Rani Hills, and parts of Boko Revenue Circle of Kamrup district are residual hills

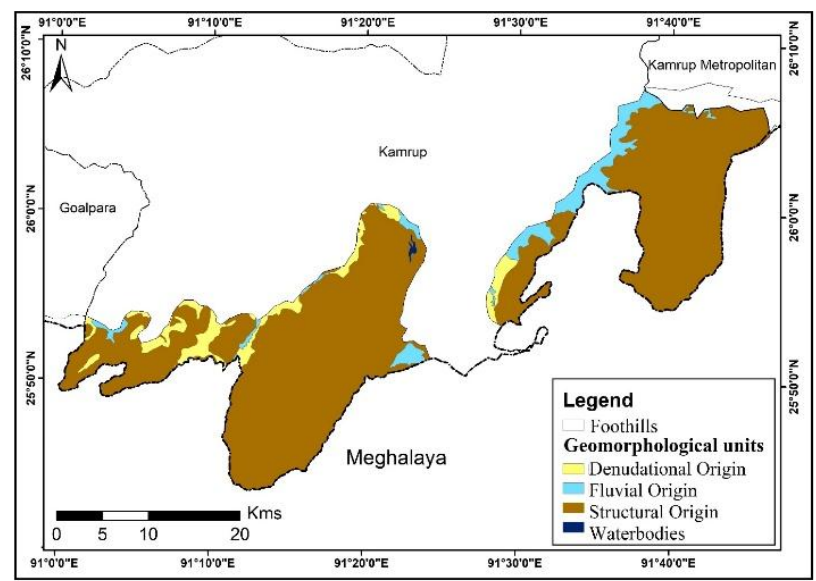

Fig. 7: Geomorphological units of the foothill belt.

Table 2: Area under different geomorphic units of the study area.

\begin{tabular}{|lll|}
\hline Geomorphic Unit & Area $\left(\right.$ in $\left.\mathrm{km}^{2}\right)$ & Area (in \%) \\
\hline Structural Origin & 674.07 & 86.61 \\
Fluvial Origin & 55.20 & 7.10 \\
Denudational Origin & 47.80 & 6.14 \\
Waterbodies & 1.20 & 0.15 \\
Total Area & 778.27 & \\
\hline
\end{tabular}




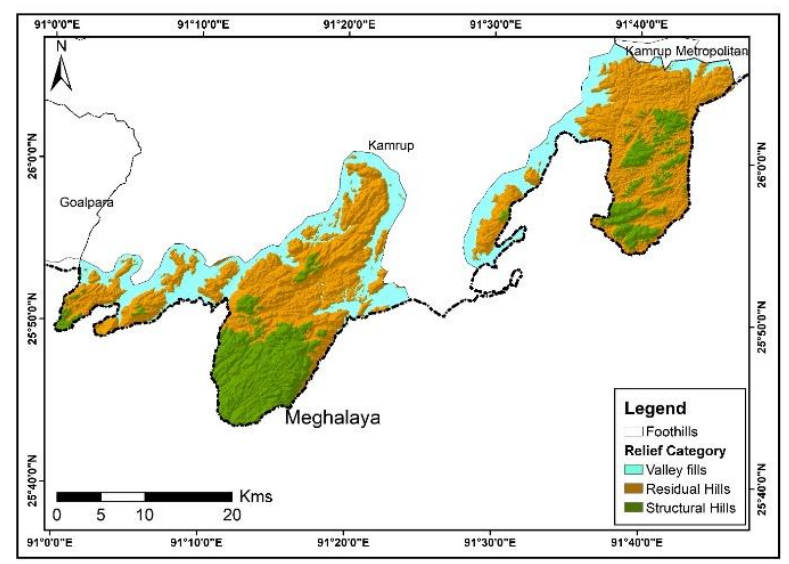

Fig. 8: Relief divisions of the foothill belt.

and occupy a total area of $377.7 \mathrm{~km}^{2}$, i.e. $48.53 \%$ of the foothills of the district.

\section{c) Structural Hills}

Structural hills of the Archaean gneissic complex are found in the southern part of the area. These range from 800 to $1124 \mathrm{~m}$ above mean sea level in the foothill zone. These are distributed in the southernmost part of Kamrup district in Boko Revenue Circle, Talimara, Garbhanga, and Rani hills. The area covered by the structural hills occupies a total area of $109.2 \mathrm{~km}^{2}$ (Table 3).

\section{Aspect}

Aspect is the direction of the surface. Aspect is the directional slope measurement. One common way is to divide aspects into eight different directions (N, NE, E, SE, S, SW, W, and NW) and to treat aspects as categorical data. The aspect and slope angle of an area is determined by the difference in incident solar radiation in mountains. It influences the occurrences of soil erosion either directly or indirectly. Aspect is measured clockwise in degrees from $0^{\circ}$ to $360^{\circ}$, where $0^{\circ}$ is north-facing, $90^{\circ}$ is east-facing, $180^{\circ}$ is south-facing, and $270^{\circ}$ is west-facing showing the orientation of slope. The aspect of the foothill zone is analyzed for the directional measure of the slope. South-East $\left(123.80 \mathrm{~km}^{2}\right)$, South $(97.61$ $\mathrm{km}^{2}$ ), South-West $\left(79.56 \mathrm{~km}^{2}\right)$, and North-West $\left(115.17 \mathrm{~km}^{2}\right)$ are the dominant aspect observed in the foothill zone of the study area (Fig. 9).

\section{Hillshade}

Hill-shading is a technique used as shaded relief to view the terrain, illuminated by a hypothetical source of light. The illumination value for each raster cell is determined based on slope and aspect, and its orientation to the light

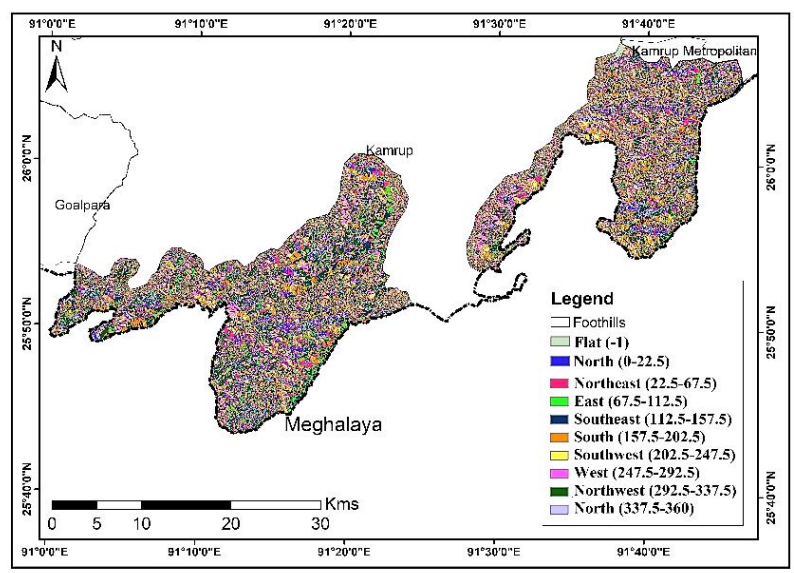

Fig. 9: Aspects of the foothill belt.

source. Hillshade gives a ground representation of the slope of the terrain. Hillshade of the terrain of the foothill zone is represented in Fig. 10.

\section{Triangular Irregular Network (TIN)}

A Triangular Irregular Network is commonly known as TIN. A Triangulated Irregular Network (TIN) is a representation of a continuous surface of triangular facets made to represent the surface. Triangular irregular networks (TIN) have been used to represent surface morphology using GIS. SRTM (DEM) is used to create the TIN of the foothill zone. The TIN model of the foothill belt is a description of the relief using unique color cum shaded relief to depict elevation and surface (Fig. 11).

\section{CONCLUSIONS}

In the study area, distinct geomorphological units such as Valley fill, Residual hill, Structural hills have been delineated. The analysis of the geology, hydrogeology, relief profile, TIN, and geomorphic units can be useful in the management the of foothill zone. The information generated at the geomorphic sub-unit level could be effectively used for prioritizing the areas for adoption of appropriate soil and water conservation measures, river basins management, hazards mitigation, geo-environmental planning. Thus, the

Table 3: Area under different Relief Unit of the Study Area.

\begin{tabular}{|lll|}
\hline Relief & Area $\left(\right.$ in $\left.\mathrm{km}^{2}\right)$ & Area (in \%) \\
\hline Valley Fill & 291.37 & 37.44 \\
Residual hill & 377.70 & 48.53 \\
Structural Hill & 109.20 & 14.03 \\
Total Area & 778.27 & \\
\hline
\end{tabular}




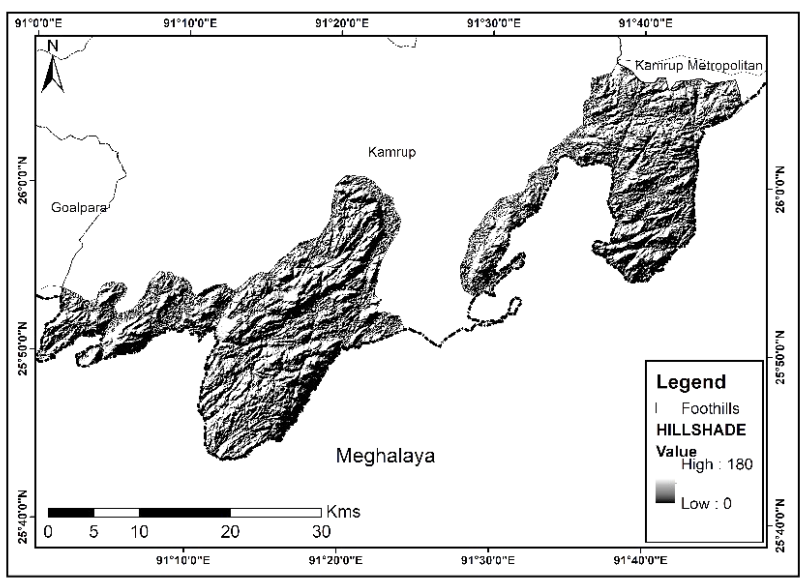

Fig. 10: Hillshade of the foothill belt.

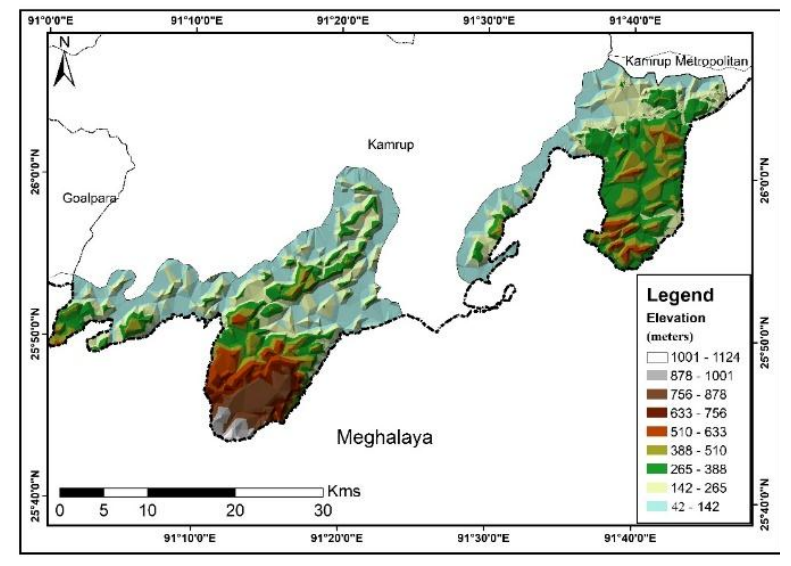

Fig. 11: TIN showing elevation of the foothill belt

Table 4: Area under different aspect classes of the study area.

\begin{tabular}{|lll|}
\hline Aspect Class (in degrees) & Area under different aspect classes (in sq. km) & Area (in \%) \\
\hline Flat & 13.39 & 1.72 \\
North & 51.90 & 6.67 \\
North-East & 76.43 & 9.82 \\
East & 73.87 & 9.49 \\
South-East & 123.80 & 15.91 \\
South & 97.61 & 12.54 \\
South-West & 79.56 & 10.22 \\
West & 77.52 & 9.96 \\
North-West & 115.17 & 14.80 \\
North & 69.05 & 8.87 \\
Total Area & 778.27 & \\
\hline
\end{tabular}

foothill belt along the Kamrup district of Assam, with the unique geomorphic characteristics and diverse foothill ecology needs proper management. By detailed terrain analysis, proper management and sustainable development can be implemented.

\section{REFERENCES}

Bolstad, P.V. and Stowe, T. 1994. An evaluation of DEM accuracy: Elevation, slope, and aspect, Photogramm. Eng. Remote Sens., 60(11): 1327-1332.

CGWB. 2012. Ground Water Information Booklet. Ministry of Water Resources, New Delhi, India.

Cooke, R.U. and Doornkamp, J.C. (ed.) 1990. Geomorphology in Environmental Management: A New Introduction. Clarendon Press, Oxford.

Dramis, S., Guida, D. and Cestari, A. 2011. Nature and Aims of Geomorphological Mapping. In: Smith, M J., Paron, P. and Griffiths, J. (eds.), Geomorphological Mapping: Methods and Applications. Elsevier, London, pp. 39-74.

Dykes, A.P. 2008. Geomorphological maps of Irish peat landslides created using hand-held GPS. J. Maps, 5: 258-276.
Manjare, B.S. 2013. Morphometric slope analysis of part of Salbardi and the adjoining region of Amravati District, Maharashtra, and Betul District of Madhya Pradesh, India. Indian J. Geomorphol., 18(2): 59-67.

Manjare, B.S., Jambhulkar, P., Padhye, M.A. and Girhe, S.S. 2020. Digital terrain analysis and geomorphological mapping using remote sensing and GIS: A case study from Central India. Sust. Manag. Land Res.Indian Persp., 6(1): 327-345.

Paron, P. and Claessens, L. 2011. Makers and Users of Geomorphological Maps. In: Smith, M.J., Paron, P, Griffiths, J. (eds.) Geomorphological Mapping: Methods and Applications. Elsevier, London, pp. 75-106.

Prasad, N. and Sarkar, R. 2011. Terrain evaluation: A review. Int. J.Curr. Res., 3(7): 296-301.

Saha, S., Paul, G.C. and. Hembram, T.K. 2020. Classification of terrain based on geo-environmental parameters and their relationship with land use/ land cover in Bansloi River basin, Eastern India: RS-GIS approach. Appl Geomat., 12: 55-71.

Summerfield, M.A. 1997. Global Geomorphology: An Introduction to the Study of Landforms. Longman, Essex, England

Wilson, J.P., \& Gallant, J.C. 2000. Terrain Analysis Principles and Applications. John Wiley and Sons, New York, 479.

Wood, J.D. 1996. The geomorphological characterization of digital elevation models. Doctoral Thesis, University of Leicester, United Kingdom. 